Isis, 1977, 68 (No. 242) Pp. $284-87$.

\title{
ROBERT BOYLE'S ANONYMOUS WRITINGS
}

By Joseph Agassi

The following brief study touches upon a very small fraction of the vast anonymous theological literature of modern times. The very concept of anonymity has a diversity of flavors, from the oriental and ancient Western, through the medieval, to the modern: proper anonymity is possible only in a culture where authorship is usually boasted of, and where the mock ascriptions of the kind we find either in the Song of Songs or in the Book of Splendour (vulgarly described as forgeries) is out of the question to the point that it is normally looked upon as a form of forgery. That is to say, properly anonymous books were not written before the scientific revolution. Dating this revolution can be somewhat flexible. Some historians take 1600 or thereabouts as the proper cut-off date, with the burning of Giordano Bruno at the stake as the last act of its kind of flagrant medieval barbarism. Some take it to be the year 1660, the date of the founding of the Royal Society of London and the institution of its standards of scientific protocol - standards that were adopted as a matter of course by all its daughters.

Robert Boyle, who was the brain behind the institution of these standards, was one of the originators and founding fathers of that society and its acknowledged leading intellect; even Newton addressed him with a frank humility uncharacteristic of his other dealings. And Boyle was a very prolific writer who published many theological works, some of them anonymous.

Boyle's first publication, Seraphick Love, published first anonymously and later under his own name, is of great historical importance. It defends natural religion and declares research to be the natural worship of God. When John Evelyn read it in manuscript he wept; he was moved to call for a meeting, chaired by John Wilkins, in which the foundation of the society, later named the Royal Society, occurred.

\footnotetext{
- Department of Philosophy, Boston University, Boston, Massachusetts 02215; Department of Philosophy, Tel Aviv University, Tel Aviv, Israel.

I am grateful to John H. Lavely of Boston University for his comments on the final draft.
} 
That Boyle published that work anonymously and then under his own name is obviously a mark of the hesitance and shyness of a young beginner, justified both by the ambitious nature of the work and by the fact that it has a strongly personal touch: in it the author recommends research as a sublimation of unrequited love. Though the personal touch almost never left Boyle and so betrayed his authorship of some anonymous theological works, the mask of anonymity of his later works is puzzling - except perhaps the anonymity of his powerful Protestant and Papist, written in the period preceding the Glorious Revolution, when an avalanche of anonymous theological works descended on England. Both that literature and the anonymity are politically explicable, but not so the rest of Boyle's anonymous output.

The particular interest in the rest of his anonymous writings derives from the fact that they are theological and written in the days when theology was of supreme concern both politically and scientifically. Canons of toleration cum separation of religion from both science and politics were soon established. At least in part the success of their implementation was due to intellectual activities, in which Boyle had a significant influence. And so, the study of Boyle's anonymous output may serve as a useful case study in the history of a whole genre: the anonymous theological works in the Age of Reason.

Any approach to Boyle's writings has to take account of two major figures in the field, and the present note will consider only them. First is Thomas Birch, the celebrated author of the only eighteenth-century history of the Royal Society, who edited Boyle's Works ${ }^{l}$ and included in his edition all of Boyle's anonymous works we know of, except Protestant and Papist, and at least one, perhaps more, anonymous work not by Boyle (see Sec. 7 below). Second is the famous Yale physiologist and bibliophile J. F. Fulton, whose Boyle's Bibliography is a classic, in a number of respects quite a monumental study and a model of scholarship, and generally a very careful study. ${ }^{2}$

\footnotetext{
${ }^{1}$ Thomas Birch, The Works of the Honourable Robert Boyle, 5 vols. (London, 1744); $2^{\text {nd }}$ ed., 6 vols. (London, 1772; reprinted Hildesheim: Olms, 1965-1966).

2 John Fulton, A Bibliography of the Honourable Robert Boyle (Oxford Bibliographical Society, 1933); (2nd ed., Oxford: Clarendon Press, 1961).
} 
1. In 1675 a book was published containing Some Considerations About the Reconcileableness of Reason and Religion by "T. E., A Lay-Man" and The Possibility of Resurrection by Robert Boyle. Fulton was "unable to identify" T. E., which is quite surprising. ${ }^{3}$ He was able to identify the author of Protestant and Papist by his style, ${ }^{4}$ but not T. E., whose style is so much more Boylean. This in spite of the fact that Fulton himself notices that possibly T. E. stands for roberT boylE. ${ }^{5}$ This, incidentally, is not as arbitrary as it sounds, since it was quite customary then to invert one's name. Thus. Boyle's friend Oldenburg, at times signed his name as Grudenbol (see D.N.B.).

2. It is even more surprising that Fulton says about Judging of Things Said to Transcend Reason that "its authorship is not established," 6 in spite of the style and the fact that it is published together with Boyle's Things Above Reason and the interlocutors in these two dialogues have the same names and are identical, as the Advertisement to the second dialogue hints.

Clearly, Fulton's care is caused by the want of explanation for the fact that (the title is “... Things above Reason ... By a F.R.S. To which are annexed by the publisher (for the affinity of the subject) [sic!] ... Things Said to Transcend Reason ... by a Fellow of the Same Society." This double anonymity is very queer and strongly asks for explanation. But if Fulton, on the basis of evidence from "style and content" identifies the first F.R.S. with Boyle, in spite of evidence to the contrary, he cannot escape identifying the two authors, whom the publisher distinguishes from each other only by implication and likewise for an unknown purpose. In any case, Fulton's caution seems to be rooted in the desire for an explanation.

3. In each of Boyle's anonymous works save Protestant and Papist there are passages repeating almost literally other passages published in Boyle's name. We can compare the

\footnotetext{
${ }^{3}$ Ibid., p. 84 (1933); p. 86 (1961).

${ }^{4}$ Ibid., p. 108 (1933); p. 11,6 (1961).

${ }^{5}$ Ibid.

${ }^{6}$ Ibid., p. 93 (1933); p. 98 (1961).

${ }^{7}$ Ibid., p. 94 (1933); p. 99 (1961).
} 
views of T. E. with those of Boyle's "Excellency." 8 There, are many other parallels, which the curious will easily find for themselves such as by checking in the index to the collected works for references to Bacon, Descartes, Hobbes, and others, as well as to specific doctrines characteristic of Boyle regarding the limits of reason, miracles, and so forth. It is thus very difficult not to attribute these works to Boyle. Yet the puzzle remains: why were they published anonymously? And Fulton's caution is quite understandable in view of this puzzle.

4. Here, then, is my proposed solution. There exists a letter from John Beale to Boyle dated October 17, 1663, ${ }^{9}$ in which Beale, by Boyle's "command," criticizes an unnamed theological work. Evidently the work was then in manuscript. He offers criticism, both general and specific. His general criticism is an expression of dissatisfaction with the overemphasis which "we" - that is, Boyle - lay on differences between the Christian sects coupled with an expression of a wish for reconciliation. His specific criticism is of Boyle's theory of God's attributes, which he either rejected or misunderstood, and of Boyle's attack on Socinus, who, in his view, should not be attacked.

5. It was Boyle who asked for criticism, and it is he who hated dispute. These two characteristics do not go well together, and I suggest that Boyle was doubly careful not to enter into dispute. Perhaps Boyle asked Beale to criticize him in order to determine whether dispute was likely to arise. In any case, my conjecture is that Boyle published his ideas, which Beale criticized separately, either anonymously or after Beale's death or both. Here is the list:

* Protestant and Papist was published anonymously in 1687. after Beale's death (probably 1683; see D.N.B.).

* The attack on Socinus was published anonymously by “T. E., a Lay Man.”

* The view on God's attributes was published anonymously (1681) in Judging of Things Said to Transcend Reason. This explains the very artificial break of this work from Things Above Reason with which it forms one dialogue.

\footnotetext{
${ }^{8}$ Works, Vol. III, pp. 432a and 530b; Vol. IV, pp. 15 and 155.

${ }^{9}$ Ibid" Vol. V, p. 437b; Vol. VI, p. 341.
} 
* In 1685, after Beale's death, Boyle published his High Veneration of God. Fulton's comment on it is this:

'The loose sheets this paper consists of, having been written at somewhat distant times and places, and hastily tack'd together...' So the 'Advertisement' reads, and perusal of the text convinces one of its honesty. There is little in [it] ... to recommend either the book or its author, and one finds it difficult to recognize in $[i t] \ldots$ the hand that penned ... ${ }^{10}$

This work includes, in the main, Boyle's doctrine of God's attributes, which, to repeat, I conjecture he did not want to publish previously under his own name. This may explain the postponement and the hectic way of publication. (By the way, contrary to Fulton's claim, its style is distinctly Boyle's: it is easy "to recognize in it the hand that penned one of Boyle's earliest publications, his Seraphic Love of 1659.)"

Let me also mention in this connection the fact that Boyle accepted Beale's criticism at last, and in his will he created a fund to organize sermons in agreement with Beale's view. The subject of these sermons was to be, in the language of Boyle's will, "the proof of Christian Religion against notorious Infidels, viz. Atheists, Theists, Pagans, Jews and Mohammedans, not descending lower to any controversies, that are among Christians."

6. Thus, it seems that my conjecture, based on characteristics normally attributed to Boyle (a critical attitude plus a dislike of dispute), explains what manuscripts Beale's letter refers to, the anonymity of three of Boyle's works, and the background of another. It does not explain why Boyle published his Protestant and Papist anonymously in spite of Beale's previous death. It also fails to explain the style of this work. This latter failure of my hypothesis is very serious, as I wish to explain now.

7. Stylistically all the anonymous works attributed to Boyle are unmistakably in his own style save Protestant and Papist and Free Discourse Against Swearing. The Discourse has some Boylean characteristics; nevertheless Fulton unhesitatingly declares that it is an imitation. For my part, I wonder if it is not a parody. However, the vulgarity of some of its anecdotes (especially the one about two friends accidentally meeting in a whorehouse) makes it beyond dispute that the author is not the gentle and pious Boyle. I do not know

\footnotetext{
${ }^{10}$ Bibliography, p. 98.
} 
how Birch came to publish it in Boyle's Works. Perhaps it was an impish move on his part: he may have liked the parody.

As to the style of Protestant and Papist, Fulton thinks it is typically Boylean. In a sense it is very much so. But the brevity and outspokenness are very uncharacteristic of Boyle and this (a) may be explained as an outcome of its expedient politics, and (b) may explain his reluctance to publish it in his own name. The strongest evidence, which seems to be sufficient, that Boyle was the author is the subtitle: Protestant Prejudices. Compare this title with two other simultaneous anonymous works: Protestant and Popish way of interpreting the Scriptures, impartially compared ... and Protestant certainty; or a short treatise showing how a Protestant may be assured of the articles of his faith ...

Nevertheless, although Boyle's style is unusually prolix everywhere, here it is terse and quick.

8. Is it possible that Protestant and Papist was published anonymously because Boyle was afraid to insult the spirit of Beale? I do not think so. Indeed, though Beale was intellectually against interdenominational theological disputes, politically he was distinctly anti-Catholic. As if to exclude this hypothesis, he wrote Boyle a letter on March $3,1672,{ }^{11}$ in which he expressed his (purely political) anti-Catholic sentiment while also recommending an enclosed anti-Catholic volume (for publication?). I do not know what volume it was, whether Boyle agreed to finance its publication, or whether it resembles in any way Boyle's own work on the same topic of a decade and a half later.

Nevertheless, we may say this: Boyle and Beale alike saw anti-Catholicism as political rather than intellectual, and there is almost nothing political penned by Boyle; hence the peculiarity of Protestant and Papist. This may seem more so if we remember that the little political he did write - an odd letter and an odd passage in Occasional Reflections was, indeed, quite terse. Perhaps he thought terseness became political writing; perhaps terseness expressed his aversion to politics and reluctance to meddle in it. Be that as it may, there is no doubt that Protestant and Papist is more political than theological in nature as well as in thrust; and the view that it is Boyle's is not well founded but is thus far unchallenged.

${ }^{11}$ Works, Vol. V, p. *500b: Vol. VI, p. 437. 